\title{
Using Dictogloss Technique to Enhance Student's Skill in Writing Narrative Text
}

\author{
Aouriaza Intik Anak Pingan, Nur Ehsan Bin Mohd Said
}

\begin{abstract}
This research aimed to identify the process of improving students' skill in writing a paragraph orientation of narrative text for the Year 6 students of Sekolah Kebangsaan Nanga Jagau through Dictogloss technique. The researcher carried out an Action Research in two cycles. Participant observations, field notes and teacher's reflections were the instruments to gather the data. Statistical description is used to analyse the data obtained from pretest and post-test. Purposive sampling technique is applied and 12 students from class $\mathrm{X} \mathrm{C}$ became the sample of this research. The results of this research showed that there was an improvement of the students' ability in writing a paragraph orientation of narrative text. 50.67 was the mean score for writing test 1 . As a result of applied Dictogloss technique, cycle 1 gained 59.33 as the mean score and improved $8.66 \%$. Next, the result of the cycle 2 showed that their mean score was 69.50 and attained improvement of $18.83 \%$. Diverse educational contexts through the process of teaching and learning looked presentable than it was before. Furthermore, the implementation of the technique received positive feedbacks from the English teacher and students. To conclude, Dictogloss technique can enhance students' ability in writing a paragraph orientation of narrative text.
\end{abstract}

Index Terms - Narrative Text, Writing Skill, Dictogloss Technique.

\section{INTRODUCTION}

Writing is one of the productive abilities that involve the ability to plan, generate, organize and translate ideas into a reading text. Meyers (2005) described writing as a way of producing language, which we naturally do when expressing something in writing. According to Richards and Renandya (2002), writing is the most difficult skill for second or foreign language learners to master. The generation, organization and translation of these concepts through a comprehensible text are one of the challenges they face. If they are weak in their language skills, the difficulty becomes more obvious. Therefore, teachers who teach English should be creative and choose the appropriate teaching technique.

Dictogloss is one of the teaching writing techniques introduced by Ruth Wajnryb in 1990. The original dictogloss procedure was designed to offer an alternative to traditional grammar teaching through written dictation. 'Dictogloss' is the word derives after the combination of 'dictation' and 'glossary.' The word dictation refers to a person's action, reading a passage out loud and the listeners write down (dictated) what is uttered. A glossary is the listing of words

Aouriaza Intik Anak Pingan, Department of Innovation in Teaching \& Learning, Faculty of Education, National University of Malaysia, Selangor, Malaysia.

Nur Ehsan Bin Mohd Said, Department of Innovation in Teaching \& Learning, Faculty of Education, National University of Malaysia, Selangor, Malaysia. alongside them with their definitions. 'Gloss' is the learner's rephrased word. Dictogloss is used as language integrated learning technique and students collaborate to reconstruct a text that they have heard. Dictogloss comprises several steps that assist the students to improve their writing skills. The Dictogloss technique also combines listening and writing ability which helps students to study and produce their own narrative text.

A narrative refers to a text that describes the story and informs the reader or listener. A narrative text contains certain features such as events sequencing, complication, coda, resolution and orientation. Writing a narrative text is the most difficult skill for students in Sekolah Kebangsaan Nanga Jagau. The primary issue in writing a narrative text was their struggle to explore and express their thinking, their vocabulary and tenses, to make good sentences and how to start writing. Therefore, this research aims to use the 'Dictogloss' technique in enhancing student's skill in writing a narrative text. This research also aims to explore how far the use of the 'Dictogloss' technique can enhance the student's skill in writing a narrative text. The research questions are as follow; 1) What are the processes of improving students' skill in writing narrative text through 'Dictogloss' technique? 2) How effective is the students' learning when 'Dictogloss' is applied in the teaching writing?

\section{LITERATURE REVIEW}

Ghaith (2002) claimed that, "Writing is a complex process that allows writers to explore thoughts and ideas, and make them visible and concrete." It means that, writing involves mental and physical process of a writer in communication activity. Raymond (1980) defined that "Writing is a way of learning in which none of us can write much of interest without first thinking, probing, observing, asking questions, experimenting, and reading". His view literally means that as soon as we start writing, we acquire a lot of things unconsciously too, because we should do some activities, such as observing and reading, to obtain information about a subject we want to write. Moreover, Langan (2001) also stated that writing is a skill like driving, typing, or cooking and like any skill that can be learned through practice.

Anderson and Anderson (2003) defined narrative as a piece of text which tells a story and, in doing so, entertains or informs the reader or listener. In the first person, narratives can be presented or told whether the narrator is one of the characters in the story and in the third person when the narrator is outside the story. Meanwhile, Woodson (1982) states narrating are when you tell a story and when you describe actual or fictional events which are arranged in 
chronological order or sequence. Orientation is a part of narrative text, the definition of orientation by Anderson (2003) is a part where the writers tell about the setting of the scene, where and when the story happened, introduce the participants of the story and what is involved in the story. It includes character, place setting and time setting.

Jacob and Small (2003) gave their view about dictogloss, "Dictogloss is an integrated skills technique in learning a language in which students assignment together to reconstruct version of text read to them by their teacher". This mark out that dictogloss is a technique in language teaching that can combine listening skills, speaking skills, reading skills and writing skills. Additionally, Vasiljevic (2010) says "Dictogloss is a classroom dictation activity where learners listen to a passage, note down key words and then assignment together to create a reconstructed version of the text". The basic procedure of dictogloss is dictation. The objective is not by any means to replicate the words by words, merely to bring as closely as possible the meaning and style of the text.

Ruth Wajnryb (1990) introduced the four stages in dictogloss procedure to teach writing. To start writing with dictogloss, the teacher first brings up the theme by presenting the subject. After a few minutes of chatting, the teacher starts the text reading. The learners are asked to listen to the story attentively, and write any words, phrases, or sentences that they can remember (Thornbury, 1999).

Initially, the teacher presents the dictation at a much slower pace. Learners just have to think and concentrate listening to the text's universal definition. In the second dictation, they listen to teacher reading the text at native speaker speed, they individually have make a brief notes such as key words or phrases which can help them to reconstruct the text but not whole sentences (Wajnryb, 1990). Learners are given the opportunity to verify the information and notes reviewing (if needed to be done) in the third listening. A short 5-minute break between the second and the third listening gives them a chance to discuss their notes and identify the points they need to focus on (Vasiljevic, 2010).

Learners do discussion on what they have listened then try to construct a new text version based on their common ways and means. The informational content should not be different and should be grammatically correct (Wajnryb, 1990). Learners correlate their text with the various reconstruction and original writings of other learners and make corrections if necessary. They discuss the choice of language. Ideally, the original text should not be seen by them until after their own versions have been analysed (Wajnryb, 1990). The original text is shown after the groups completed their work. Students make comparison, analyse and revise their writings. Their versions can also be stuck up on the board or the walls together with the original one (Harmer, 2004). This action research was guided by few previous researches. Cindy Claudia et. al. (2017) conducted a two cycle's action research on 'Improving Students' Ability in Writing a Paragraph Orientation of Narrative Text through Dictogloss Technique". This research aimed to identify the process of improving students' ability in writing a paragraph orientation of narrative text through dictogloss technique. The observation checklist sheet, field notes, and interview rubric analysis were the instruments to gather the data. Purposive sampling technique was applied and 27 students from class $\mathrm{X}$
C were selected as the sample. The outcomes of the research exposed the improvement of the students' ability in writing a paragraph orientation of narrative text and the class situations were not bored as students gave attention to the lesson. Based on this research, the researcher aims to discover how the process improves students' ability in writing a narrative text. Researcher also wanted to integrate variations of dictogloss techniques throughout the processes of improving students' skill in writing narrative text.

Hujjatul Islamiyah and Kuni Hikmah Hidayati (2016) aimed at finding how the use of the dictogloss technique through Classroom Action Research (CAR) improves Thai students' listening comprehension. The samples were 20 Thai students of class $6 / 1$ at the school. The data were collected from listening comprehension tests and were analysed by using a qualitative approach. $55 \%$ of students in the first cycle achieved the target score, and was improved into $75 \%$ in the second one. This leads to the conclusion that the students' improved listening comprehension was because dictogloss combines top-down and bottom-up processing which is appropriate with the students' need. This research has guided the researcher in collecting qualitative data. However, the researcher focuses more on the writing skills of the students in this research. Two different stories will be used for the narrative texts.

A quasi experimental study by Evi Shofiah (2015) aimed to find out "The Effectiveness of Dictogloss Technique towards Students' Narrative Writing". 114 students from the first grade were chosen as the population and she has conducted this technique in teaching writing. By using writing test as the instrument for pre-test and post-test, students were required to write a narration of text. She found significant difference between students' narrative writing scores who were equipped with dictogloss technique and those who were not. By applying this kind of technique, students see the simpler way to write or produce a narration of text. The quantitative design used in the research is not suitable for this research as only 12 students were involved. By referring to this study, the researcher decided to be concerned with all factors involved in it, such as the teaching strategy, classroom management, the materials, students' vocabulary mastery, and the equipment that can influence the goals of teaching writing and its learning process.

By referring to the reasoning described, researcher would like to adapt the original dictogloss procedure and suggests the two hypotheses :1) Dictogloss can enhance the students' writing skill through the six stage process; initiation stage, input stage, independent stage, independent internalization stage, interactive stage and final internalization stage. 2) The students' learning is effective when dictogloss is implemented in the teaching of writing.

\section{RESEARCH DESIGN}

Action research was selected as the research design for this study. Researcher applies the four stages in the Kemmis and McTaggart's Model (1988) which included planning, acting, observing and reflecting to analyse what occurred in the writing classroom before and after the dictogloss implementation. Qualitative methods were used to collect the 
data and the data attained from pre-test and post-tests are analysed using statistical description. The procedures of action taken were pre research stage, need analysis stage, intervention planning stage, intervention implementation stage, observing and post-intervention stage.

Considering to the dictogloss procedures suggested, the procedures of dictogloss used by the researcher in teaching of writing narrative text for the implementation stage are as follows:

1. Initiation stage - Warming up to the topic and instructional conversation.

2. Input stage - Teacher play or read aloud the text. Learners make a brief notes.

3. Independent stage - Learners reproduce their own words as much as the original texts. Teacher provides feedbacks (individual or whole-group feedback).

4. Independent internalization stage - Comparing personal texts to the original.

5. Interactive stage - Learners shift from a self-correcting to a peer-correcting activity.

6. Final internalization stage - Learner scrutinizes the text and does reflection.

\section{RESEARCH INSTRUMENTS}

The instrument tools used by the researcher to gather the data were the participant observation checklist, field notes, teacher's reflections and writing test. The research participants are from Sekolah Kebangsaan Nanga Jagau, a rural school in Kanowit, Sarawak. Only one class, Class X C, became a sample of this research which consists of 12 students. Purposive sampling technique was applied. Qualitative methods were used to collect data from participant observation checklist, field notes and teacher's reflections. Gathered data from pre-test and post-test are analysed using statistical description. Triangulation method is used to validate the data. Questionnaire for profiling was also carried out.

\section{A. Writing Test}

The test consisted of a writing test whereby the students were instructed to write a narrative text depended on the determined topic. That writing test was set twice for pre-test and post-test. The topic for pre-test was about the story of Oliver Twist and the topic for post-test was the story of Gulliver's Travels. All the 12 students were provided the same test and sixty minutes were given to do the test. The researcher used face and content validity to obtain the test validation. Hence, before conducting the research, the researcher did consultation to her advisors, SISC+ English teacher and the English teacher at the school where the researcher carried out the research. The researcher adapted the analytic scoring rubric for writing to fulfil the reliability of the test. It was established by Jacobs et al's (1981) as cited in Hughes' book. Based on the rubric, students' reconstructed version of a text were marked from every part of writing namely content, organization, language use, vocabulary, and mechanics. In addition, the researcher also asked the English teacher's help to assess students' writing.

\section{B. Participant observation}

Participant observer needs to fill in the observation schedule prepared by the researcher. Students' behaviours, insights or engagement levels during the lessons and as well as to indicate interest in the activities throughout the lesson were observed. The all three lessons used the same observation schedule. Huah (2012) stated that this method was used to decrease the biasness of the data. The participant observer was an English teacher who had 8 years experiences in teaching profession. The quality of the data therefore depends on the diligence of the participant observer, rather than on technology such as tape recorders.

\section{Participant observation}

Reflections are taken after each lesson. The purpose of reflections is to analyse the situations, obtain evidence of the researcher's practice and responds accordingly. Engagement in the reflection mechanism enables researcher to corroborate what she does. All weaknesses found in the first cycle were revised for the next cycle. The trustworthiness of the findings of the reflections follows Lincoln and Guba's (1985) trustworthiness condition of credibility, transferability, dependability and conformability.

\section{ANALYSIS AND FINDINGS}

In this study, pre-test and post-test were used to collect data. There was an improvement of writing scores among the students. The result of the analysis showed that cycle 1 displayed mean score of 59.33 and cycle 2 displayed mean score of 69.50. The data from participant observation, field notes and teacher's reflections implicated that students showed less willing and confused in the first lesson but towards the second and third lesson they look enthusiastic, active in participation, reflective, creative and enjoyed.

The researcher collected some data to be analysed when carrying out this research. This research was based on action research and data from class $\mathrm{X} \mathrm{C}$. The data are calculated to show the mean score in both cycles and the process of teaching and learning in the course of research. The results summary for cycle 1 and cycle 2 was shown in table 1 .

Table I. Students Writing Score in Cycle 1 and Cycle 2

\begin{tabular}{|c|c|}
\hline The Students' Results in & The Students' Results in \\
Cycle 1 & Cycle 1 \\
$\Sigma X 1=712$ & $\Sigma X 2=834$ \\
$\overline{\mathrm{x}} 1=59.33$ & $\overline{\mathrm{x}} 2=69.50$ \\
\hline
\end{tabular}

The researcher conducted three meetings in this research. Writing test 1 , cycle 1 and cycle 2 were set up in the three research meetings. Class X C of SK Nanga Jagau was the research sample and comprised of 12 students. Before carrying out the Dictogloss technique in cycle 1 , the researcher conducted a writing test 1 for students to determine their writing scores. The mean score for the writing test 1 was 50.67 . In pursuit of the students' writing scores, Dictogloss technique is implemented in cycle 1 . In this research, the researcher as the classroom teacher observed the classroom and made some field notes, meanwhile the participant observation did some observation checklist. 
The first cycle was particularly on the paragraph orientation in which the teacher informed the material today concerning narrative text. The teacher then presented the students with a descriptive text. The teacher explained what narrative text is and its general structure, language features, gave the narrative text an example and explained how to correctly punctuate the narrative text. The teacher then introduced the Dictogloss technique to the students. Teacher gave an explanation about the Dictogloss technique procedures to the students as well, and instructed them to pair up. At the beginning, the teacher showed the students a picture of 'Oliver Twist'. The teacher then introduced certain vocabulary to help the students to write. The audio dictation was given twice, in the first dictation the students were prohibited to write any information, but after the first dictation some keywords could be noted. The students then rebuilt their own paragraph orientation in pairs from the story. They corrected the work of the other groups and gave it back to them. They finally edited their writings and presented them to the teacher. The researcher and the teacher calculated students' mean score and the result was 59.33. There was an improvement from writing test 1 that was $8.66 \%$. In this research the target score of the students was $\geq 60$ and it must be achieved by $70 \%$ of the students. In cycle 1 , it was found that there were 7 of 12 students $(58.33 \%)$ who got score $\geq 60$. It means that the actions in cycle 1 were not successful and it required the researcher to carry on with the actions into cycle 2. Based on the researcher's field notes during teaching learning process in cycle 1 , the students were passive at the beginning of this cycle and until they did the task, they did not answer the teacher's question on narrative text material, nor did they ask the teacher in writing about their problems. The teacher was only sitting on her seat and did not monitor her students' work. Students preferred to ask the teacher regarding the English translation because they neglected to carry the dictionary. Some students did not finish their test until the analysis and correction stage because of the time and few student encountered difficulty and confused while writing the text. When the students wrote, they were also chattering and shrieking in the class. The researcher therefore decided to continue the action to the next cycle.

In cycle 2, the research continued and the teacher improved the explanation of the students' weaknesses based on cycle 1 results. The teaching process here was almost the same with cycle 1, but the teacher gave a different story, it was 'Gulliver's Travel'. The results of cycle 2 showed that their mean score was 69.50 and improved by $18.83 \%$. The researcher was pleased with her attempts to enhance the writing skills of the students in narrative text. Students were able to create narrative text and could easily evaluate their idea using Dictogloss technique. They were more comfortable to talk to their partner until they got the whole story. It has also been demonstrated by its improved scores from cycle 1 to cycle 2 . The researcher has made decision to stop the Action Research because it was successful. The researcher therefore did not have to alter the course of action. Based on the combined evaluation results of the researcher and the participant observation, the assumption deduced was that the implementation of Action Research using Dictogloss technique to enhance the ability of students to write a paragraph orientation of the narrative text was suitable for the planning that had been carried out by the researcher earlier. Under this circumstance, every part was outlined as efficient as possible so that the writing activities could be carried out effectively.

Table II. The Difference Score between Writing Test 1, Cycle 1 and Cycle 2

\begin{tabular}{|c|c|c|c|c|}
\hline No. & Name & $\begin{array}{c}\text { Writing } \\
\text { Test } 1\end{array}$ & Cycle 1 & Cycle 2 \\
\hline 1 & Respondent A & 58 & 66 & 80 \\
\hline 2 & Respondent B & 44 & 54 & 60 \\
\hline 3 & Respondent C & 46 & 52 & 64 \\
\hline 4 & Respondent D & 50 & 54 & 66 \\
\hline 5 & Respondent E & 52 & 62 & 68 \\
\hline 6 & Respondent F & 56 & 68 & 70 \\
\hline 7 & Respondent G & 42 & 50 & 62 \\
\hline 8 & Respondent $\mathrm{H}$ & 54 & 60 & 72 \\
\hline 9 & Respondent I & 56 & 64 & 74 \\
\hline 10 & Respondent J & 40 & 50 & 60 \\
\hline 11 & Respondent K & 52 & 66 & 78 \\
\hline 12 & Respondent L & 58 & 68 & 80 \\
\hline \multicolumn{2}{|c|}{ Total $\Sigma N=12$} & 608 & 712 & 834 \\
\hline \multicolumn{2}{|c|}{ Mean } & 50.67 & 59.33 & 69.50 \\
\hline
\end{tabular}

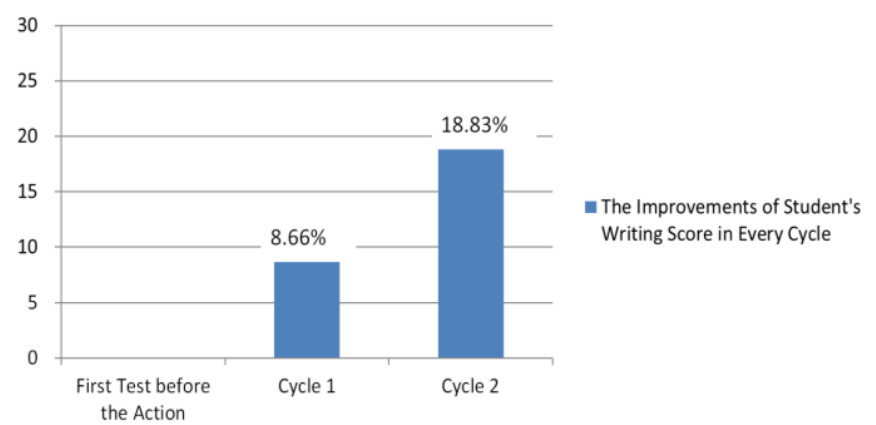

Figure 1: The Improvement of Students' Writing in Every Cycle

The research findings revealed that, improvement was achieved in teaching learning process using Dictogloss technique. From the field notes, English teacher's observation checklist and reflections, Dictogloss technique was very practical for students in writing, if in cycle 1 some stages could not be accomplished however in cycle 2 all stages were completed. The teacher also had a good time in the teaching learning process. In conclusion, students' ability in writing a paragraph orientation of narrative text could be improved by using Dictogloss technique.

\section{A. The Improvement of the Learners' Writing Skill}

Based on the teacher's observation, in the first lesson, students had difficulty following instructions but they were able to follow the instructions with the teacher's and peer's guidance. The second lesson showed that the students were less willing to involve in the activities. However, they could respond to the narrative text towards the last part of the activities. In the third lesson, the students showed an interest in writing the story and committed themselves well during the 
dictation. Dictogloss encourages active and creative thinking skills, as students should reconstruct their texts using their own choice of phrases, sentences or even words. Some of them can even put in precise and appropriate information creatively outside the range that included in the teacher's written text. The activity of reconstruction marks the consciousness, discussion, knowledge acquisition and points of view. Students apply reasoning skills to analyse the new constructed texts for the initial as well. It implicates that dictogloss is efficient to build up student's dynamic and creative reasoning skill as demonstrated in the increment of their creativity in cycle 2 . Only 5 students $(41.67 \%)$ in cycle 1 have shown their creativity and it rises to 10 students $(83.33 \%)$ in cycle 2 .

\section{B. Wider Range of Strategies and Processes Use in} Completing the Writing Task through Dictogloss Technique

Researcher field notes recorded that the learners acquired to employ a broader range of strategies to complete their writing tasks, for example exchanging information, pairing discussion, grouping discussion, searching the suitable choice of words and similarities in dictionaries, outline, rephrasing and so on. They also reflect more on the outcomes of their learning by providing instant evaluation during the two stages; analysis and correction. They gained understanding into their language deficiencies by comparing the first authentic text against the reconstructed text. In such a way, they could observe both their improvement and their downfall to better perform their next writing tasks. Dictogloss offers contextual opportunities beneficial to groupthink and cooperation between learners to clarify the issues of reconstruction activities in a cooperative manner. They learned more easily with other people, in which they shared their obtained skills, findings, creative views and different explorations with friends who have gained their mastery in various methods. Students reached greater awareness of involvement within their learning groups, as shown by the improvement in cycle 2 from cycle 1 . There are 7 students $(58.33 \%)$ in cycle 1 who have shown participation, and it rises to 12 students $(100 \%)$ in cycle 2 .

\section{Implementation of Dictogloss in the Teaching of Writing and Learners' Learning Effectiveness}

The findings of the research convey that learners achieved efficient learning upon the implementation of dictogloss during the teaching writing process. Based on the teacher's reflections, respondents had difficulty in completing the first lesson's production activity. The researcher applied the dictogloss technique in the second and third lessons to guide the students to perform the activities. Dictogloss was always emphasized during the completion of the activities, as it helped them to comprehend what the text was all about. It would ensure that respondents are exposed to writing skills by using the dictogloss technique. Dictogloss imparts greatly on the motivation of the learners, as shown by their extent optimistic behaviour towards writing tasks and activities. It provides guideline that assists them to deal with their struggles in writing so they obtain a progressively assured feeling and learning integration as well as a more advanced view of themselves as a student. They are prompted to accomplish their writing assignments because the cause of their poor motivation (the problems in writing) has been cleared up. They participate actively in the composing activities as their motivation increases. They are quick to react to the lesson presentation by the teachers, and simulate more enthusiastic, joyful, lively, and participative within the writing activities.

\section{SignificAnce Of The Study}

This research may give benefits for researchers and stakeholders as an information or alternative strategy in teaching writing as well as interesting technique to improve the writing skills of the student. The writing skills help students to express their ideas or to share information in writing. Since writing is among the attainable abilities, this study aims to promote collaboration between researchers and stakeholders in educational research. More research on dictogloss technique, provided that dictogloss technique is appropriate as well as effectual, could be done to teach other English competencies and alternate mastery.

The research results imply that dictogloss able to become a substitute technique to enhance the writing skills of the learners and to establish successful learning, as it has great consequences not only on the scores of the students, but also on the student's behaviour improvement as well. English teachers as a facilitator should therefore run the writing classes smoothly to optimise the writing skills of their learners. Dictogloss is among the applicable possible methods. It can enhance the learners' writing skills and generate productive learning, particularly in composition classrooms. Essentially, everything can be the subject of the matter; however it should depend on the necessity, level, intrigues and syllabus of learners. The text outline should be constructed before the reconstruction phase in the dictogloss process.

\section{DISCUSSION}

After doing the research, obviously Dictogloss technique applied in the writing class improves student's writing skills. Student's progression of writing ability was evident from the outcome of the post-test in cycle 1 in which some aspects of writing a paragraph orientation of narrative text, in particular aspects of content (character, place and time setting), organization and mechanics, have been improved. Grammar and vocabulary were, however, still low. Students could not apply suitable words in written text in vocabulary. In grammar, the students found it difficult to use simple past tenses.

The implementation of the Dictogloss intervention through the six stages; the initiation stage, the input stage, the independent stage, the independent internalization stage, the interactive stage and the final internalization stage improved the skills of the students in writing narrative texts. Better management of content (character, place setting and time), organization and mechanics was evident in the Dictogloss technique process, which covered paragraphs. Elizabeth, et. al. (2005) stated that working together can help students learn more effectively and perform writing stages. In the meantime, the students felt better to organize the words in paragraph and to improve their mechanics (spelling and punctuation). The students work in pairs in the implementation of the 
Dictogloss technique. Harmer (2002) added that ideas are generated by two or more students than when the researchers work in their own right. They have the opportunity to edit all aspects of writing.

They also assess and check their writing by sharing with the other pairs and the teacher, as Tompkins (1994) states through this sharing, student make contact with genuine audiences who respond in meaningful ways to their writing. In addition, the research findings also showed that the students spent time writing effectively and were able to complete their writing on time. These summed up that the dictogloss technique do increased the time for productive learning. Like Gettinge in Elliot (2000), who identifies three possible aspects of learning time. The first time is used for instruction, the second time is spent, and the third time is productive learning time, which means that the more things can be done in a certain period.

Vasiljevic (2010) stated that the teacher facilitates writing by providing background information and helping students with unfamiliar words during the preparatory stages. Therefore, the preparation stage aims at giving students a thematic drilling and introduces them with the text language. It definitely helps them to write and master new vocabulary. At the dictation stage, students receive certain keywords as a way to reconstruct the text. After that, the students are helped by their friend in the reconstruction phase, because they learn to reconstruct a text using the vocabulary and keywords they have written together. And the last step in analysis and correction is that students stay brave enough upon present own text, correct it and revise it together.

\section{LIMITATION OF STUDY AND SUGGESTIONS}

The researcher would have liked to have more time to work with the students on their writing skills. More time would have also allowed more opportunities to implement other writing strategies. This research is not a comprehensive study as it is restricted to one primary school only which is Sekolah Kebangsaan Nanga Jagau, Kanowit. Any decision, formulation and generalization can only be referred to the school only. This research was unable to control the influence of external factors that may affect the variables of the research and one of them is the level of student intelligence.

The researcher hoped that the future researchers will continue and explore this action research by building up few perspectives which were not unfolded herein, including assess the utilization of dictogloss for teaching writing and its learning process. Authors of English text book must incorporate dictogloss meant for educators to teach the language skills. It must be followed by good plan of action and should incorporate the reorganisation of text draft before the reformation task. In school, the headmasters should promote and assist the English language teachers to carry out dictogloss during English period, particularly writing by being supportive and giving them motivation. Headmasters could also provide the teaching media and facilities required in the classroom for the implementation.

\section{CONCLUSION}

In line with the statements of the problems, data analysis and detailed discussion, exist few essential details related to the consequences of dictogloss implementation within the writing process that guide the researcher to conclude the followings: 1) Implementation of the dictogloss process within the writing lesson able to enhance the students' writing ability. The process leads the students to grasp and utilize the five elements of writing while composing a text logically as well as contextually; 2) Effective students' learning is obtained once dictogloss is enforced in the writing lesson. In each writing stages, they are seen a lot of spirited, involved in actively, full of strategies, attentive participants, accountable, independent plus reflectively open towards their products of writing. Students progressively skillful and inventive when composing content too.

APPENDIX

\begin{tabular}{|c|c|c|}
\hline \multicolumn{3}{|c|}{ Analytic Scoring Rubric } \\
\hline \multirow[t]{4}{*}{ CONTENT } & $30-27$ & $\begin{array}{l}\text { EXCELLENT TO VERY } \\
\text { GOOD - substantive, } \\
\text { thorough development of } \\
\text { topic, effective and } \\
\text { appropriate details of topic } \\
\text { or story. }\end{array}$ \\
\hline & $26-22$ & $\begin{array}{l}\text { GOOD TO AVERAGE - } \\
\text { adequate range, adequate } \\
\text { development of topic, } \\
\text { sufficient details of topic or } \\
\text { story. }\end{array}$ \\
\hline & $21-17$ & $\begin{array}{l}\text { FAIR TO POOR - little } \\
\text { substance, inadequate } \\
\text { development of topic and } \\
\text { detail. }\end{array}$ \\
\hline & $16-13$ & $\begin{array}{l}\text { VERY POOR } \\
\text { non-substantive, not } \\
\text { pertinent, or not enough to } \\
\text { evaluate. }\end{array}$ \\
\hline \multirow[t]{4}{*}{ ORGANIZATION } & $20-18$ & $\begin{array}{l}\text { EXCELLENT TO VERY } \\
\text { GOOD: fluent expression, } \\
\text { ideas clearly } \\
\text { stated/supported, } \\
\text { well-organized, logical } \\
\text { sequencing, cohesive. }\end{array}$ \\
\hline & $17-14$ & $\begin{array}{l}\text { GOOD TO AVERAGE: } \\
\text { somewhat choppy, loosely } \\
\text { organized but main ideas } \\
\text { stand out, logical but } \\
\text { incomplete sequencing. }\end{array}$ \\
\hline & $13-10$ & $\begin{array}{l}\text { FAIR TO POOR: non - } \\
\text { fluent, ideas confused or } \\
\text { disconnected, lacks logical } \\
\text { sequencing. }\end{array}$ \\
\hline & $9-7$ & $\begin{array}{l}\text { VERY POOR: does not } \\
\text { communicate, no } \\
\text { organization, or not enough } \\
\text { to evaluate. }\end{array}$ \\
\hline \multirow[t]{2}{*}{ VOCABULARY } & $20-18$ & $\begin{array}{l}\text { EXCELLENT TO VERY } \\
\text { GOOD: } \text { effective } \\
\text { word/idiom choice and } \\
\text { usage, word form mastery. }\end{array}$ \\
\hline & $17-14$ & $\begin{array}{l}\text { GOOD TO AVERAGE: } \\
\text { occasional errors of } \\
\text { word/idiom form, choice, } \\
\text { usage but meaning not } \\
\text { obscured. }\end{array}$ \\
\hline
\end{tabular}




\begin{tabular}{|c|c|c|}
\hline & $13-10$ & $\begin{array}{l}\text { FAIR TO POOR: frequent } \\
\text { errors of word/idiom form, } \\
\text { choice, usage, meaning } \\
\text { confused or obscured. }\end{array}$ \\
\hline & $9-7$ & $\begin{array}{l}\text { VERY POOR: little } \\
\text { knowledge of English } \\
\text { vocabulary, idioms, word } \\
\text { form, or not enough to } \\
\text { evaluate. }\end{array}$ \\
\hline \multirow[t]{4}{*}{ LANGUAGE USE } & $25-22$ & $\begin{array}{l}\text { EXCELLENT TO VERY } \\
\text { GOOD: effective complex } \\
\text { constructions, few errors of } \\
\text { agreement, tense, number, } \\
\text { word order/function, } \\
\text { articles, pronouns, } \\
\text { prepositions. }\end{array}$ \\
\hline & $21-18$ & $\begin{array}{l}\text { GOOD TO AVERAGE: } \\
\text { effective but simple } \\
\text { construction, } \\
\text { problems in complex } \\
\text { construction, several errors } \\
\text { of agreement, tense, } \\
\text { number, } \\
\begin{array}{l}\text { order/function, articles, } \\
\text { pronouns, prepositions but } \\
\text { meaning seldom obscured. }\end{array}\end{array}$ \\
\hline & $17-11$ & $\begin{array}{l}\text { FAIR TO POOR: major } \\
\text { problems } \\
\text { simple/complex } \\
\text { constructions, frequent } \\
\text { errors of negation, } \\
\text { agreement, number, word } \\
\text { order/function, articles, } \\
\text { pronouns, prepositions } \\
\text { and/or fragments, run-ons, } \\
\text { deletion, meaning confused } \\
\text { or obscured. }\end{array}$ \\
\hline & $10-5$ & $\begin{array}{l}\text { VERY POOR: virtually no } \\
\text { mastery of sentence } \\
\text { construction rules, } \\
\text { dominated by errors, does } \\
\text { not communicate, or not } \\
\text { enough to evaluate. }\end{array}$ \\
\hline \multirow[t]{3}{*}{ MECHANICS } & 5 & $\begin{array}{l}\text { EXCELLENT TO VERY } \\
\text { GOOD: demonstrates } \\
\text { mastery of conventions, } \\
\text { few errors of spelling, } \\
\text { punctuation, capitalization, } \\
\text { paragraphing. }\end{array}$ \\
\hline & 4 & $\begin{array}{l}\text { GOOD TO AVERAGE: } \\
\text { occasional errors of } \\
\text { spelling, punctuation, } \\
\text { capitalization, } \\
\text { paragraphing but meaning } \\
\text { not obscured. }\end{array}$ \\
\hline & 3 & $\begin{array}{l}\text { FAIR TO POOR: frequent } \\
\text { errors of spelling, } \\
\text { punctuation, capitalization, } \\
\text { paragraphing, poor } \\
\text { handwriting, meaning } \\
\text { confused or obscured. }\end{array}$ \\
\hline
\end{tabular}

\section{REFERENCES}

[1] Anderson, Mark and Anderson Kathy. 2003. Text Types in English 3. SouthYarra: Mcmillan.

[2] Bahagian Pembangunan Kurikulum. 2011. Dokumen Standard Kurikulum Sekolah Rendah Bahasa Inggeris SK. Putrajaya: Kementerian Pendidikan Malaysia.

[3] Claudia, C., Sada, C., and Wardah. 2017. Improving Students' Ability in Writing a Paragraph Orientation of Narrative Text Through Dictogloss Technique. Jurnal Pendidikan dan Pembelajaran Untan.

[4] Elisabeth, Barkley F.et al. 2005. Collaborative Learning Technique. (1st Ed). San Fransisko: Jossey - Bass Publisher.

[5] Elliot, John. 1991. Action Research for Educational Change. Philadelphia: Open University Press Milton Keynes.

[6] Fetterman, D. M. 1998. Ethnography Step by Step (2nd Ed). Thousand Oaks: Sage Publications.

[7] Flynn, Naomi and Rhona Stainthorp. 2006. The Learning and Teaching of Reading and Writing. West Sussex: Whurr Publishers Limited.

[8] Ghaith, Ghazi. 2011. Writing: Cycle I, II and III of Basic Education. $\begin{array}{lllll}\text { Retrieved on } \quad \text { August, } & 8 & 2018 & \text { from }\end{array}$ http:/nadasisland.com/ghaith-writing.html.

[9] Harmer, Jeremy. 2002. How to Teach Writing. Harlow: Pearson Education Limited.

[10] Huah, G. L. 2012. A Practical Guide to Writing Your Action Research. Selangor Darul Ehsan: Penerbitan Multimedia Sdn. Bhd.

[11] Hughes, Arthur. 2003. Testing for Language Teachers (2nd Ed). Cambridge: Cambridge University Press.

[12] Hujjatul Islamiyah and Kuni Hikmah Hidayati. 2016. Improving Students' Listening Comprehension by Using Dictogloss Technique at Darul Quranilkarim School Narathiwat - South Thailand. Jember: IECO Vol.1 pp.70-78.

[13] Jacob, George and John Small. 2003. Combining Dictogloss and Cooperative Learning to Promote Language Learning. The Reading Matrix, 3 (1).

[14] Kemmis, S and McTaggart, R. 1988. The Action Research Reader. Third Edition. Deakin University Press, Victoria.

[15] Kirklees Council of United Kingdom. 2003. Health and social guidelines: questionnaires. Retrieved on April 29, 2018 from https://www.kirklees.gov.uk/community/yoursay/Questionnaires.pdf

[16] Langan, John. 2001. English Skill with Reading 7th edition. New York: Mc Graw Hill.

[17] Lincoln, Y. S., and Guba, E. G. 1985. Naturalistic Inquiry. Newbury Park, CA: Sage Publications.

[18] Mertler, A. C. 2009. Action Research: Teachers as researchers in the classroom (2nd ed.). Thousand Oaks, CA: Sage.

[19] Meyers, Allan. 2005. Gateways to Academic Writing: Effective Sentences Paragraph and Essay. New York: Longman.

[20] Raymond, James C. 1980. Writing (Is an Unnatural Act). New York: Harper and Row Publishers.

[21] Shofiah, Evi. 2015. The Effectiveness of Dictogloss Technique towards Students' Narrative Writing. Jakarta: UIN.

[22] Tompkins, G. E. 1994. Teaching Writing: Balancing Process and Product (2nd Ed). New York: Macmillan College Publishing Company, Inc.

[23] Thornbury, Scott. 1990. How to Teach Grammar. London: Longman.

[24] Vasiljevic, Zorana. 2010. Dictogloss as an interactive method of teaching listening comprehension to L2 learners. English Language Teaching, 3 (1), 41-52.

[25] Wajnryb, Ruth. 1990. Grammar Dictation. Oxford: Oxford University Press.

[26] Woodson, Linda. 1982. From Cases to Composition. Glenview. Illinois: Scott, Foresman and Company. 